\title{
ASSESSING THE ROLE OF WATER USERS ASSOCIATIONS IN OPERATING AND MAINTAINING THE IMPROVED IRRIGATION SYSTEM IN EGYPT
}

\author{
El-Hadad ${ }^{*}$ F., El-Gamal T. and Mady A. \\ Water Management Research Institute, National Water Research Center, Ministry of Water \\ Resources and Irrigation, El-Qanater Elkhayria, El-Qalyobia, Egypt
}

*Corresponding author: elhadad1652005@yahoo.com

Received 27 November, 2019

Accepted 29 April, 2020

\section{ABSTRACT}

The current study investigated the influence of Water Users Associations (WUAs) in the operation and the maintenance of the facilities of improved areas in Egypt. With the establishment of irrigation improvement projects, it was planned that WUAs would play an important role in improving water management and ensuring the sustainability of the improved system through enhancing the cooperation between farmers, scheduling the irrigation and maintaining the improved Mesqas (distributaries).

The current study aims to check the actual situation after the implementation of irrigation improvement projects through collecting data from samples according to design questionnaires in the improved areas, and analyzing the collected data to investigate the influence of these associations.

The results showed that the influence of WUAs in Egypt was still very limited. Irrigation practices were close to the old trend, which was targeting by irrigation improvement projects. The improved system was operated based on the natural relationships between farmers, with no predefined irrigation schedule targeting improving water management. The operator was the main person, and his role was just to arrange the irrigation based on the reservation of the farmers. Old lifting points were still used in the new system. This gave the farmers the chance to work individually, which could decrease the direct conflicts between them, but it had negative impact on water use efficiency. The maintenance of the system was poor, and the target was just to make the system work without considering the sustainability of the system.
The study discussed the reasons behind the weak influence of WUAs including the characteristics of such organizations and different factors that affect their performance. In addition, the study suggested the required steps to improve the capacities of these organizations and to enhance the coordination between farmers including the precise distribution of water supply, and the support from the government.

Keywords: Farmers' Coordination; Water Users Associations; Irrigation Improvement

\section{INTRODUCTION}

The idea of farmers' participation started by the middle of 1970s. By 1980s, several countries began to implement Irrigation Management Transfer (IMT) programmes whereby irrigators were encouraged to participate in the operation and the maintenance of their irrigation systems (Plusquellec, 2002). Farmers' participation, based on Chambers and Lenton is "an approach by irrigation agencies, to increase irrigation performance by providing effective incentives and conditions that enable farmers, both individually and collectively, to accept and fulfill irrigation management responsibilities where and when appropriate" (Hvidt, 1998).

In Egypt, the idea of farmers' participation started within a research project (Egyptian Water Use and Management Project - EWUP) that took place between 1979 and 1984. With the implementation of irrigation improvement projects since the middle of 1980's and until now, thousands of WUAs at Mesqas and canals levels were established (MacDonald, 2008). From the other hand, the period since the emanating of the idea until now has 
witnessed dynamic changes in the society and dynamic change in water-lifting techniques and both has adversely affected the natural cooperation between farmers, and such decrease in natural cooperation was a challenge for the new water organizations that adversely affected their performance.

The weakness of the new water organizations was not limited to Egypt. There was a doubt about the impact of such organizations in improving the irrigation, and in fulfilling their responsibilities in many countries, and this depends on the conditions of establishing such organizations. Burns (1992) stated, "The unfortunate truth is that most efforts to develop formal water users associations bear little lasting fruit. In short run, meetings are held, leaders chosen and rules drafted. In long run, such organizations often only exist on paper, with little new activity beyond what farmers had already been doing".

The problem of this research is the shortage of legal evaluation of WUAs in terms of its role on water management and farmer participation since such approach has started. Improving water management and farmers participation is the break bone of WUAs principals that is currently implemented countrywide, and therefore it essential to evaluate the influence of WUAs on these points.

The study was carried out in the improved areas in Kafr El-Sheikh and El-Behera governorates (Mit Yazid and El-Mahmoudia command areas). A survey was conducted in some branch canals for few consecutive seasons, and the collected data was analyzed statistically. The results were discussed to define the reasons behind such weakness and the suggested actions to improve the capacities of these organizations.

\section{Different types of water users associations and their successful chances}

Based on Groenfeldt (Groenfeldt and Svendsen, 2000), the industrial countries adopted Participatory Irrigation Management (PIM) policies as a matter of fiscal necessity. Groenfeldt commented that this approach is more important for the developing countries, and he suggested that farmers do not have to do the technical work themselves, and they can employ specialists who work on their behalf. Such approach of hiring specialists to do the technical works is defined as business-type approach, contrary to social-type approach (Plusquellec, 2002). Business-type organizations almost replace the governmental agencies in their roles. They are legal entities that can enter into contracts, and they have the power to enforce rules and regulations. These associations hire professional staff for the actual management, and farmers are not directly involved in the management of their systems.

Business-type WUAs had successful stories in some countries, such as Mexico, Turkey, Colombia and Taiwan. Mexican experiment is considered as the first successful PIM in the developing countries. Based on Kloezen et al (1997) "international organizations have advocated the Mexican IMT program as "the transfer model" to other countries, apparently due to the program's scale and speed of implementation." Besides being developed on strong organizational base, Kloezen et al (1997) mentioned some characteristics for the strengthening of these organizations including working closely and support from the government at the beginning. They added, "Unlike in Sri Lanka and Nepal, for instance, the Mexican IMT program does not aim to maximize direct participation in $\mathrm{O}$ and $\mathrm{M}$ of all users but aims to involve farmers in representative governance." Another characteristic of business-type water user associations is the big area served by each association. The average size of the 406 associations created in Mexico by the end of 1999 was about 7,000 ha, with some reaching 30,000 hectares. In Turkey, the average size of the 222 associations, created as of the end of December 1997, was 5,300 ha, with some exceeding 20,000 ha (Johnson, 1997 and Svendsen, 2001).

On the other hand, social associations are seldom self-sustaining. A multi-tiered organization is emerging as a possible solution for the management of large-scale irrigation schemes with a large number of small farmers. It is not only time consuming but even counterproductive to organize so many associations and groups at each level. Plusquellec (2002) concluded, "The social water user associations that were developed for the purpose of providing cheap labour for maintenance and collecting water fees were consistently found weak or paper associations. The business-type water user associations that hired staff to distribute water and ran the distribution system similar to a business operation were often very strong."

The weakness of social-type organizations is related to the size of the irrigation system. Steinberg divides irrigation systems into private, communitybased and large-scale systems, and he pointed out that participation took different forms in these different types (Hvidt, 1998). Based on Hvidt, there was a big difference in the success of WUAs between small command areas (private or community-based systems) and large command areas. Hvidt (1998) 


\section{Assessing the Role of Water Users Associations in Operating and Maintaining the Improved Irrigation System in Egypt}

stated that the success was very limited in some large command areas, such as Indus River Irrigation system (Pakistan). These organizations could success in private or community-based systems, as the requirement is already what the farmers used to do by themselves, and there is no urgent need for the complex organizations in such small systems (Burns, 1992).

WUAs in Egypt are among social-type organizations, and the irrigation system is a large-scale system. It is a typical example of multi-tiered organization. The organizations that actually found on ground are WUAs at Mesqas level, with average served area of about 20 ha. Thousands of these associations were established in different command areas. The associations for higher levels (branch canals levels and irrigation districts) were not active yet.

Factors affecting the performance of new water organizations in Egypt

Besides being social-type organizations in large-scale irrigation network, some factors adversely affected the performance and the sustainability of new water organizations. This section describes these factors.

\section{Social changes in the Egyptian rural areas}

The natural coordination between farmers around old Saqias was one of the characteristics of the Egyptian irrigation until few decades ago. Ayeb (2013) described the old collection around Saqias as "One of the rarest associations and structures that have self-sovereignty". During last decades, the rural society in Egypt have witnessed rapid social changes that affected such natural cooperation between farmers. Mahgoub (2016) stated, "Cultural values of the environment, agricultural land, public spaces, personal privacy, and many other components of culture are undergoing drastic changes due to the change of the composition of the inhabitants of the village. There is a loss of the sense of belonging to the agricultural land, which was an important part of the relationship between the villagers and their land. The only competition exits in the acquisition of electric appliances and interest in temporary migration to large cities or immigration to Arab countries." The immigration deprived agricultural labor market from the energetic members and it immersed the rural areas with consumption styles associated with different moral values. As result, the system that was elevating the connection with the land, the association, and the continuous collaborations for global benefits has adversely affected. New water organizations could not cover the absence of such natural coordination yet. Ayab (2013) evaluated the cooperation in the new organizations, based on the study conducted in Upper Egypt as "total absence of any form of effective and voluntary participation from associations' members".

\section{Weak control of the irrigation system and the} change of water-lifting technique

With the social changes, there were technical and operational changes that adversely affected the willingness of the farmers to cooperate with each other in irrigation. Since 1980's, there were a rapid change from the Saqias to diesel pumps. Such change encouraged the individual actions and decreased the cooperation between farmers in irrigation (Plusquellec, 2002 and El-Gamal, 2014).

Regarding the operational changes, there was a disability to control the irrigation system precisely during last decades. For instance, the vast replacement of Saqias by diesel pumps since the beginning of 1980's, which was mentioned above, was done without any arrangement from the government. MacDonald (2008) described this change as follows "The unregulated replacement of Saqia by diesel pumps is perhaps both a symptom and a cause of a certain degree of disengagement of the irrigation sector. In operational terms, the branch canals have tended to become a "no-man's land". Weak control of the system also led to the degradation of the irrigation network, as the result of the weak maintenance and the encroachments of the farmers, and the increase of water crises in many regions. The increase of water crises decreased the natural cooperation between farmers and the individual action became the general trend (EI-Gamal et al 2014).

\section{Historical background of establishing WUAs in Egypt}

The idea of transferring water management to new water organizations has started in Egypt during EWUP project at the end of 1970's and the beginning of 1980's. The establishment of new water organizations in the improved areas started since the middle of 1980's with USAID-IIP project that was applied in eleven command areas. In this project, over 800 WUAs were established. During the next phases of the improvement project (IIP1 \& IIP2 and III-MP), few thousands of WUAs and few hundreds of BCWUAs were established (MacDonald, 2008). This is besides WUAs that are still under development in the current phase and WUAs that were established in other regions. 


\section{Previous studies}

A previous study was conducted to evaluate the influence of WUAs in Upper Egypt (Ayeb, 2013). The study showed that WUAs do not have any actual influence and therefore there was no change on the level of reform and reorganization of the water resource. The farmers mentioned that:

- The organizations were developed without returning to the farmers or informing them before the implementation.

- The boards of WUAs were not elected, but they were nominated from the irrigation engineers.

- The meetings between the board members were rare

- The farmers were not informed about the laws and the regulations of these organizations.

In addition, the collected information showed that both farmers and engineers concern only about the physical changes from IIP, without paying attention to the institutional reforms. Most of the farmers believed that they could not share in these new organizations, and if they share, their involvement will be worthless at the end. Irrigation engineers believed that farmers are not able to operate their organizations by themselves.

Other results recorded the level of farmers' knowledge about WUAs boards. The study showed that the operator of the Mesqa was the well-known person for the farmers. The knowledge about all other members of WUA board was limited (Fig. 1). The study mentioned that the operators were nominated from the engineers of the irrigation districts.

\section{MATERIAL AND METHODS}

A questionnaire was designed to collect the required information. This study developed a questionnaire to collect the required information. This questionnaire includes four sections:

- The first section of the questionnaire is dealing with the formation process of WUA board (elected or nominated) and the usefulness of these boards;

- The second section is dealing with the responsibility for operating the improved Mesqas, and farmers' preference regarding the operation of these Mesqas;

- The third section is dealing with the responsibility for collecting the fees and the type of the documents (official or unofficial)
- The fourth checks how the irrigation is scheduled between farmers, and the role of the board in maintaining the improved Mesqa.

Data was collected from five canals, and the process continued for four consecutive seasons (winter 2015-2016, summer 2016, winter 2016-2017 and summer 2017).

In each canal and during each season, the number of the farmers who accepted the hypothesis (said yes) and the number of the farmers who rejected the hypothesis were counted. The data was checked statistically through comparing the mean of the numbers of farmers who accepted the hypothesis and the numbers of farmers who rejected the hypothesis in all canals during all seasons (Analysis of Variance - ANOVA).

The results were discussed to illustrate the reasons behind these results and the suggested steps to improve the performance of WUAs in Egypt.

\section{Studying areas}

The study was conducted in four branch canals in Mit Yazid (Middle Delta) and El-Mahmoudia (West Delta) command areas (Kafr El-Sheikh and El-Behara governorates). The selected canals represent the head and tail end regions of both command areas. Fig. (2) Presents the command areas of the investigated canals, and Table (1) presents the general information of the investigated canals.

The served areas of the investigated canals were between 628 (El-Gemeiza canal) and 5182 ha (El-Saraniya canal). The improvement activities were completed in three canals, while the improvement progress was still in the other two canals during the period of data collection. Four of the five canals were related to the last improvement phase (IIIMP), where the improvement covered Mesqas and Marwas, and only one canal was related to the first phase (IIP1), where the improvement covered the Mesqas only. The number of WUAs were between 19 in El-Gemeiza canal and 176 in El-Saraniya canal.

Regarding the availability of the water, water is almost available continuously in Nekla canal. Due to its steep slope, water is accumulated at the tail end, and water crises could only found at some subbranches due to some infrastructural problems. Mars El-Gamal is facing water shortage events at its tail end during summer seasons, and there was a dependence on the drainage water at this tail end. The tail end canals are facing water shortage and they depend on the drainage water to complete their water requirements. 


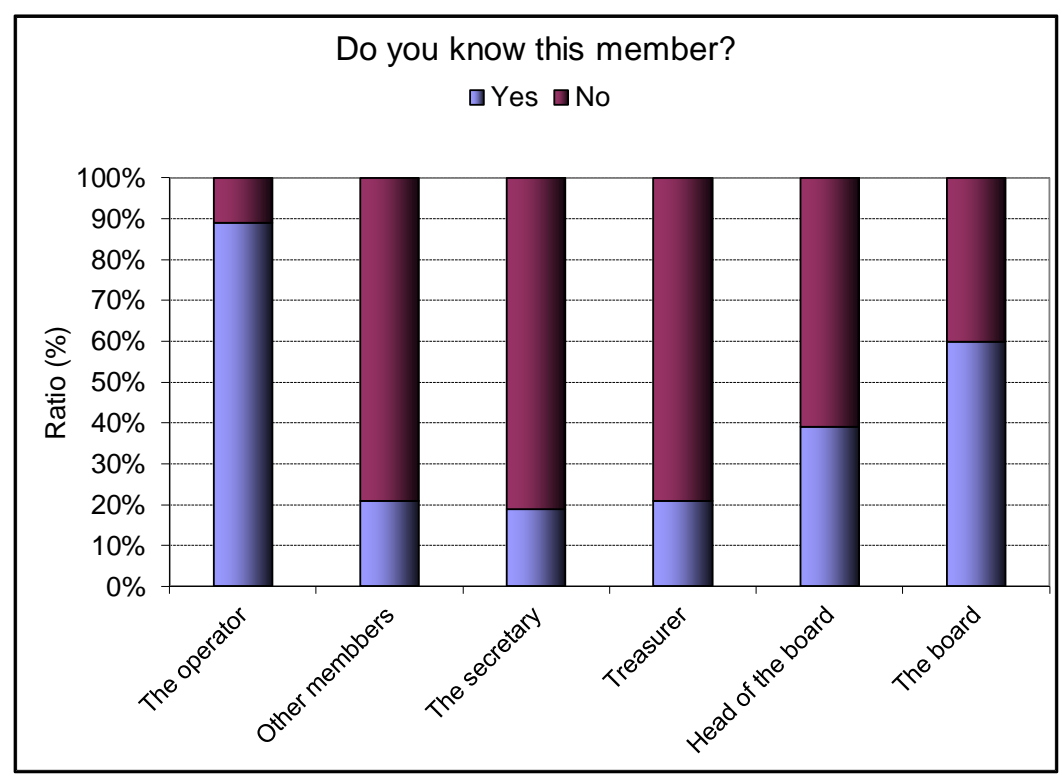

Fig. 1. The level of farmers' knowledge about their WUAs (from Ayeb -2 013)

Table 1. General information of the investigated canals

\begin{tabular}{|c|c|c|c|c|c|}
\hline Canal Name & Nekla & El-Qamahin & EI-Saraniya & Mars El-Gamal & El-Gemeiza \\
\hline Governorate & \multicolumn{3}{|c|}{ El-Behara } & \multicolumn{2}{|c|}{ Kafr El-Sheikh } \\
\hline Main canal & \multicolumn{3}{|c|}{ El-Mahmoudia } & \multicolumn{2}{|c|}{ El-Zawia } \\
\hline $\begin{array}{l}\text { Location } \\
\text { Area Served (ha) } \\
\text { No of WUAs }\end{array}$ & $\begin{array}{c}\text { Head } \\
1415.0 \\
52\end{array}$ & $\begin{array}{c}\text { Middle } \\
1612.0 \\
102 \\
\end{array}$ & $\begin{array}{c}\text { Tail } \\
5182.0 \\
176 \\
\end{array}$ & $\begin{array}{c}\text { Head } \\
4548.0 \\
73\end{array}$ & $\begin{array}{c}\text { Tail } \\
628.0 \\
19 \\
\end{array}$ \\
\hline $\begin{array}{l}\text { Improvement } \\
\text { Situation }\end{array}$ & Completed & Completed & $\begin{array}{l}\text { In progress } \\
\text { during } \\
\text { collecting } \\
\text { samples }\end{array}$ & Completed & $\begin{array}{l}\text { In progress } \\
\text { during } \\
\text { collecting } \\
\text { samples }\end{array}$ \\
\hline Improvement Phase & IIIMP & IIP1 & IIIMP & IIIMP & IIIMP \\
\hline Improvement Type & $\begin{array}{l}\text { Improvement } \\
\text { contained } \\
\text { Mesqas and } \\
\text { Marwas }\end{array}$ & $\begin{array}{l}\text { Improvement } \\
\text { contained } \\
\text { Mesqas only }\end{array}$ & $\begin{array}{c}\text { Improvement } \\
\text { contained } \\
\text { Mesqas and } \\
\text { Marwas }\end{array}$ & $\begin{array}{c}\text { Improvement } \\
\text { contained Mesqas } \\
\text { and Marwas }\end{array}$ & $\begin{array}{l}\text { Improvement } \\
\text { contained } \\
\text { Mesqas and } \\
\text { Marwas }\end{array}$ \\
\hline
\end{tabular}




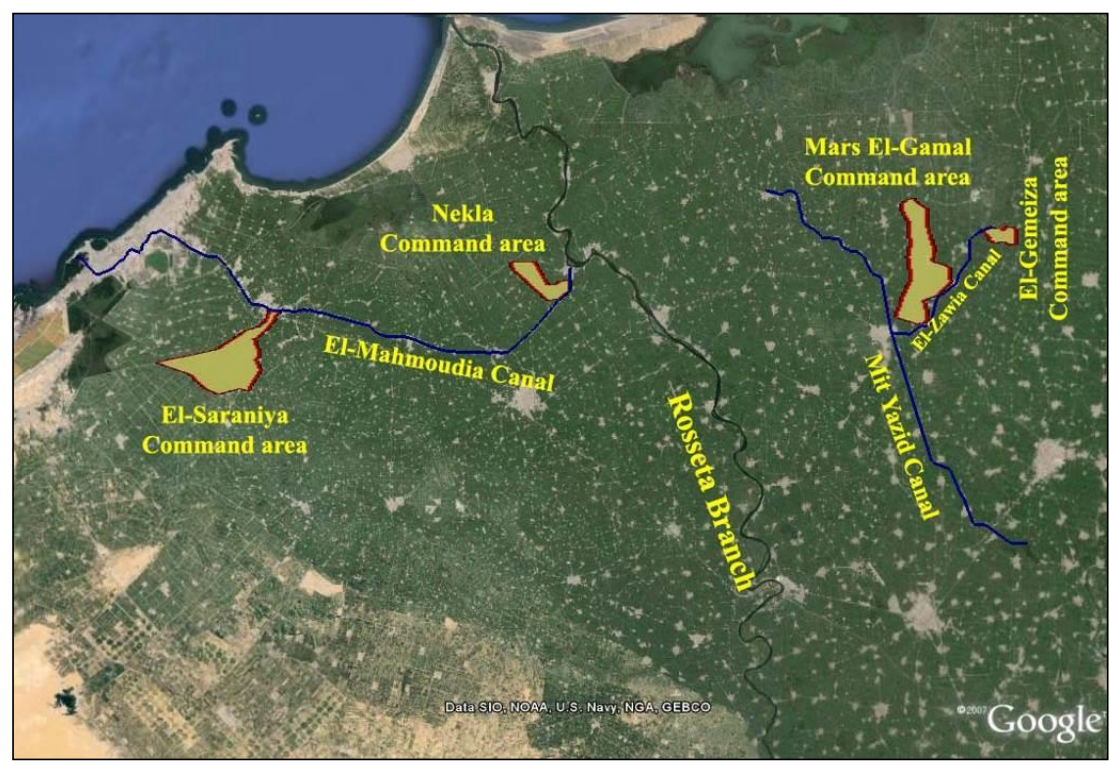

Fig. 2. The selected canals and the command areas

The investigation did not cover the five canals during each season. In the first season (winter 2015-2016), the investigation covered Nekla and Mars El-Gamal canal. The improvement was completed in the two canals within this time. El-Saraniya canal was added to the investigation in summer 2016. Canal improvement was not completed during this time. However, the investigated Mesqas in this canal was completed. In winter 2016-2017, the investigation included El-Gemeiza canal. The improvement was still in progress in the canal. The electricity was not provided to the Mesqas, and farmers were still use diesel pumps outside the pump station to pump inside the pipeline. El-Gemeiza was replaced by El-Qamahin canal in last season. El-Qamahin is related to IIP1 and it has different design characteristics, and it was completed many years ago.

\section{RESULTS AND DISCUSSION}

\section{The formation and usefulness of the WUAs}

The first part of the questionnaire checked the procedure to establish the boards of WUAs and the opinions of the farmers about the usefulness of these boards. From the collected samples in different canals through four consecutive seasons, almost all farmers believed that the boards were not elected and they were nominated (Table 2). Only in one canal during winter 2015-2016, some farmers believed that, the boards were elected. The nomination is normally done by the staff of the improvement projects or by the staff of the advisory service. The main purpose of forming the boards was to sign for the submission of the improved Mesqas to complete the official documents.

Regarding the usefulness of the boards, and from 392 samples that were collected during the four seasons, 136 farmers (35\%) believed that the boards were useful, and 256 farmers $(65 \%)$ believed that these boards were not useful. Comparing the means of Yes and No groups, (Analysis of Variance - ANOVA) proved that there was a significant difference between the two groups as presented in the next table. Farmers' opinions were different from a region to the other. In different branch canals of El-Mahmoudia command area, farmers believed that the boards were not useful. In Mars El-Gamal canal (Mit Yazid command area), considerable portion of the farmers believed that the boards were useful.

\section{The responsibility for operating the Mesqas (Operators vs. WUA board)}

Regarding the responsibility for operating the Mesqas, the questionnaire checked three items.

- The responsibility for operating the Mesqa (the operator or WUA board);

- Farmers' preference for operating the improved Mesqas; 

the Improved Irrigation System in Egypt

Table 2. Check the formation and usefulness of WUA boards

\begin{tabular}{|c|c|c|c|c|c|}
\hline \multicolumn{6}{|c|}{ The procedure to form WUA boards and are they useful? } \\
\hline \multirow{2}{*}{ Season } & \multirow{2}{*}{ Canal } & \multicolumn{2}{|c|}{ Formation } & \multicolumn{2}{|c|}{ Useful? } \\
\hline & & Elect? & Norm? & Yes & No \\
\hline W 2015-16 & $\begin{array}{c}\text { Nekla } \\
\text { Mars El-Gamal }\end{array}$ & $\begin{array}{l}0 \\
4\end{array}$ & $\begin{array}{l}36 \\
27\end{array}$ & $\begin{array}{c}6 \\
11\end{array}$ & $\begin{array}{l}30 \\
20\end{array}$ \\
\hline S 2016 & $\begin{array}{c}\text { Nekla } \\
\text { El-Saraniya } \\
\text { Mars El-Gamal }\end{array}$ & $\begin{array}{l}0 \\
0 \\
0\end{array}$ & $\begin{array}{l}36 \\
32 \\
32 \\
\end{array}$ & $\begin{array}{c}6 \\
8 \\
30 \\
\end{array}$ & $\begin{array}{c}30 \\
24 \\
2 \\
\end{array}$ \\
\hline W 2016-17 & $\begin{array}{c}\text { Nekla } \\
\text { El-Saraniya } \\
\text { Mars El-Gamal } \\
\text { El-Gemeiza }\end{array}$ & $\begin{array}{l}0 \\
0 \\
0 \\
0\end{array}$ & $\begin{array}{l}36 \\
36 \\
36 \\
36\end{array}$ & $\begin{array}{c}10 \\
4 \\
31 \\
8\end{array}$ & $\begin{array}{c}26 \\
32 \\
5 \\
25 \\
\end{array}$ \\
\hline S 2017 & $\begin{array}{c}\text { Nekla } \\
\text { El-Qamahin } \\
\text { El-Saraniya } \\
\text { Mars El-Gamal }\end{array}$ & $\begin{array}{l}0 \\
0 \\
0 \\
0\end{array}$ & $\begin{array}{c}37 \\
14 \\
15 \\
9\end{array}$ & $\begin{array}{c}6 \\
5 \\
1 \\
10 \\
\end{array}$ & $\begin{array}{c}33 \\
15 \\
14 \\
0\end{array}$ \\
\hline \multicolumn{6}{|c|}{ ANOVA (for usefulness) } \\
\hline & Sum of Squares & df & Mean Square & $\mathbf{F}$ & Sig. \\
\hline $\begin{array}{l}\text { Between Groups } \\
\text { Within Groups } \\
\text { Total }\end{array}$ & $\begin{array}{c}553.846 \\
2636.000 \\
3189.846\end{array}$ & $\begin{array}{c}1 \\
24 \\
25\end{array}$ & $\begin{array}{l}553.846 \\
109.833\end{array}$ & 5.043 & 0.034 \\
\hline
\end{tabular}

- The responsibility for collecting the fees, and the types of documents to record these fees (official or unofficial documents).

Table (3) presents the results for these three points.

Regarding the first question, $13 \%$ of the farmers believed that WUA board was responsible for the operation (49 from 389), and the rest (87\%) believed that the operator was responsible for the operation. Some farmers in many cases were mixing between the operator and the board considering that the operator was a member of the board in these cases, and these samples were ignored during the analysis. Comparing the means of Yes \& No groups, (Analysis of Variance - ANOVA) proved that there was a significant difference between the two groups.

For the second question, $16 \%$ of the farmers preferred WUA board (61 from 382), and the rest (84\%) preferred the operator. In many cases, all farmers preferred the operator. There was a significant difference between (Yes) \& (No) groups.

Regarding the responsibility for collecting fees, $18 \%$ of the farmers mentioned that WUA board collects the fess. The rest ( $82 \%)$ mentioned that the operator collects the fees, and there was a significant difference between (Yes) \& (No) groups.
For keeping the records and the type of these records, the majority of the farmers mentioned that the operator was responsible for keeping the records, and these documents are unofficial documents (notebook) to record the payment of the farmers and the expenditures.

\section{Scheduling the irrigation and the responsibil- ity for the maintenance}

The two important points were the role of WUAs boards in scheduling the irrigation between farmers and in maintaining the improved Mesqas. Table (4) presents the results for these two points.

Regarding scheduling the irrigation, $36 \%$ of the farmers mentioned that WUA board has a role for scheduling the irrigation between farmers, and $64 \%$ rejected this idea. The second group mentioned that they irrigate by reserving their turn with the operator or through arranging among themselves. In many cases, there was a misunderstanding about scheduling the irrigation. Some farmers mismatched between having pre-determined and designed schedule that aims improving water distributions and reserving their turns after each other, and they considered the last one as a schedule. Based on ANOVA analysis, there was a significant difference between the two groups. 
Table 3. Responsibility for operating the Mesqas

\begin{tabular}{|c|c|c|c|c|c|c|c|}
\hline \multicolumn{8}{|c|}{ Operator Vs. WUA Board } \\
\hline \multirow{2}{*}{ Season } & \multirow{2}{*}{ Canal } & \multicolumn{2}{|c|}{ Who Operates? } & \multicolumn{2}{|c|}{ Whose you prefer? } & \multicolumn{2}{|c|}{ Who collects fees? } \\
\hline & & Operator & Board & Operator & Board & Operator & Board \\
\hline \multirow{2}{*}{ W 2015-16 } & Nekla & 28 & 8 & 28 & 8 & 30 & 6 \\
\hline & Mars El-Gamal & 24 & 7 & 31 & 0 & 21 & 10 \\
\hline \multirow{3}{*}{ S 2016} & Nekla & 36 & 0 & 24 & 12 & 36 & 0 \\
\hline & El-Saraniya & 32 & 0 & 23 & 9 & 25 & 7 \\
\hline & Mars El-Gamal & 24 & 8 & 24 & 8 & 11 & 19 \\
\hline \multirow{4}{*}{ W 2016-17 } & Nekla & 30 & 6 & 30 & 6 & 36 & 0 \\
\hline & El-Saraniya & 31 & 5 & 31 & 5 & 32 & 4 \\
\hline & Mars El-Gamal & 36 & 0 & 36 & 0 & 36 & 0 \\
\hline & El-Gemeiza & 36 & 0 & 36 & 0 & 28 & 8 \\
\hline \multirow{4}{*}{ S 2017} & Nekla & 29 & 1 & 27 & 0 & 30 & 3 \\
\hline & El-Qamahin & 19 & 2 & 16 & 1 & 18 & 2 \\
\hline & El-Saraniya & 15 & 0 & 15 & 0 & 15 & 0 \\
\hline & Mars El-Gamal & 0 & 12 & 0 & 12 & 2 & 10 \\
\hline \multicolumn{8}{|c|}{ ANOVA (Who operates?) } \\
\hline & & & $\begin{array}{l}\text { Sum of } \\
\text { Squares }\end{array}$ & df & $\begin{array}{l}\text { Mean } \\
\text { Square }\end{array}$ & $\mathbf{F}$ & Sig. \\
\hline & Setween Groups & & 3256.962 & 1 & 3256.962 & 50.057 & 0.000 \\
\hline & Within Groups & & 1446.000 & 24 & 60.25 & & \\
\hline & Total & & 4702.962 & 25 & & & \\
\hline \multicolumn{8}{|c|}{ ANOVA (Whose you prefer?) } \\
\hline & & & $\begin{array}{l}\text { Sum of } \\
\text { Squares }\end{array}$ & df & $\begin{array}{l}\text { Mean } \\
\text { Square }\end{array}$ & $\mathbf{F}$ & Sig. \\
\hline & etween Groups & & 2600.000 & 1 & 2600.000 & 43.468 & 0.000 \\
\hline & Within Groups & & 1435.538 & 24 & 59.814 & & \\
\hline & Total & & 4035.538 & 25 & & & \\
\hline \multicolumn{8}{|c|}{ ANOVA (Who collects fees?) } \\
\hline & & & $\begin{array}{l}\text { Sum of } \\
\text { Squares }\end{array}$ & df & $\begin{array}{c}\text { Mean } \\
\text { Square }\end{array}$ & $\mathbf{F}$ & Sig. \\
\hline & etween Groups & & 2423.115 & 1 & 2423.115 & 33.580 & 0.000 \\
\hline & Within Groups & & 1731.846 & 24 & 72.160 & & \\
\hline & Total & & 4154.962 & 25 & & & \\
\hline
\end{tabular}

Regarding the maintenance of the system, 39\% of the farmers mentioned that WUA board has a role for maintaining the improved Mesqas, and the $61 \%$ rejected this idea. The difference between the two groups (Yes and No groups) was not significant. Detailed discussion showed that the question might be misleading and it depends on the type of the maintenance. The operator performs regular maintenance. In major maintenance problem, such as replacing a motor or a pump for instance, some members of WUAs boards, and may be some farmers, involve in the process.
Besides previously collected information, some additional observation from the monitoring and evaluation of irrigation improvement projects could explain the scheduling of the irrigation and the maintenance of the system.

Regarding scheduling the irrigation, all observations showed that old pumps (farmers' pumps) were still used besides the improved Mesqas (Fig. 3), and there was no attempt from the government or WUAs to stop using these pumps in the improved areas as was planned. Under such conditions, the role of the improved system in improving water use efficiency became very limited except their effect on reducing 
Assessing the Role of Water Users Associations in Operating and Maintaining the Improved Irrigation System in Egypt

Table 4. Scheduling the irrigation \& maintaining the Mesqas

\begin{tabular}{|c|c|c|c|c|c|}
\hline \multicolumn{6}{|c|}{ Scheduling irrigation and Maintenance } \\
\hline \multirow{2}{*}{ Season } & \multirow{2}{*}{ Canal } & \multicolumn{2}{|c|}{ Scheduling } & \multicolumn{2}{|c|}{ Maintenance } \\
\hline & & Yes & No & Yes & No \\
\hline W 2015-16 & $\begin{array}{c}\text { Nekla } \\
\text { Mars El-Gamal }\end{array}$ & $\begin{array}{c}8 \\
31\end{array}$ & $\begin{array}{c}28 \\
5\end{array}$ & $\begin{array}{c}7 \\
30\end{array}$ & $\begin{array}{c}29 \\
6\end{array}$ \\
\hline S 2016 & $\begin{array}{c}\text { Nekla } \\
\text { El-Saraniya } \\
\text { Mars El-Gamal }\end{array}$ & $\begin{array}{c}5 \\
10 \\
28 \\
\end{array}$ & $\begin{array}{c}31 \\
26 \\
8\end{array}$ & $\begin{array}{c}4 \\
12 \\
32\end{array}$ & $\begin{array}{c}32 \\
24 \\
4\end{array}$ \\
\hline W 2016-17 & $\begin{array}{c}\text { Nekla } \\
\text { El-Saraniya } \\
\text { Mars El-Gamal } \\
\text { El-Gemeiza }\end{array}$ & $\begin{array}{c}5 \\
6 \\
27 \\
3\end{array}$ & $\begin{array}{c}31 \\
30 \\
9 \\
33\end{array}$ & $\begin{array}{c}7 \\
4 \\
29 \\
6\end{array}$ & $\begin{array}{c}29 \\
32 \\
7 \\
30\end{array}$ \\
\hline S 2017 & $\begin{array}{c}\text { Nekla } \\
\text { El-Qamahin } \\
\text { El-Saraniya } \\
\text { Mars El-Gamal }\end{array}$ & $\begin{array}{c}6 \\
2 \\
10 \\
28\end{array}$ & $\begin{array}{c}30 \\
34 \\
26 \\
8\end{array}$ & $\begin{array}{c}8 \\
2 \\
10 \\
33\end{array}$ & $\begin{array}{c}28 \\
34 \\
26 \\
3\end{array}$ \\
\hline \multicolumn{6}{|c|}{ ANOVA (Irrigation scheduling) } \\
\hline & Sum of Squares & df & Mean Square & $\mathbf{F}$ & Sig. \\
\hline $\begin{array}{c}\text { Between Groups } \\
\text { Within Groups } \\
\text { Total }\end{array}$ & $\begin{array}{c}650.000 \\
2920.000 \\
3570.000 \\
\end{array}$ & $\begin{array}{c}1 \\
24 \\
25 \\
\end{array}$ & $\begin{array}{l}650.000 \\
121.667\end{array}$ & 5.432 & 0.030 \\
\hline \multicolumn{6}{|c|}{ ANOVA (Maintenance) } \\
\hline & Sum of Squares & df & Mean Square & $\mathbf{F}$ & Sig. \\
\hline $\begin{array}{c}\text { Between Groups } \\
\text { Within Groups } \\
\text { Total }\end{array}$ & $\begin{array}{c}384.615 \\
3455.385 \\
3840.000\end{array}$ & $\begin{array}{c}1 \\
24 \\
25\end{array}$ & $\begin{array}{l}384.615 \\
143.974\end{array}$ & 2.671 & 0.115 \\
\hline
\end{tabular}

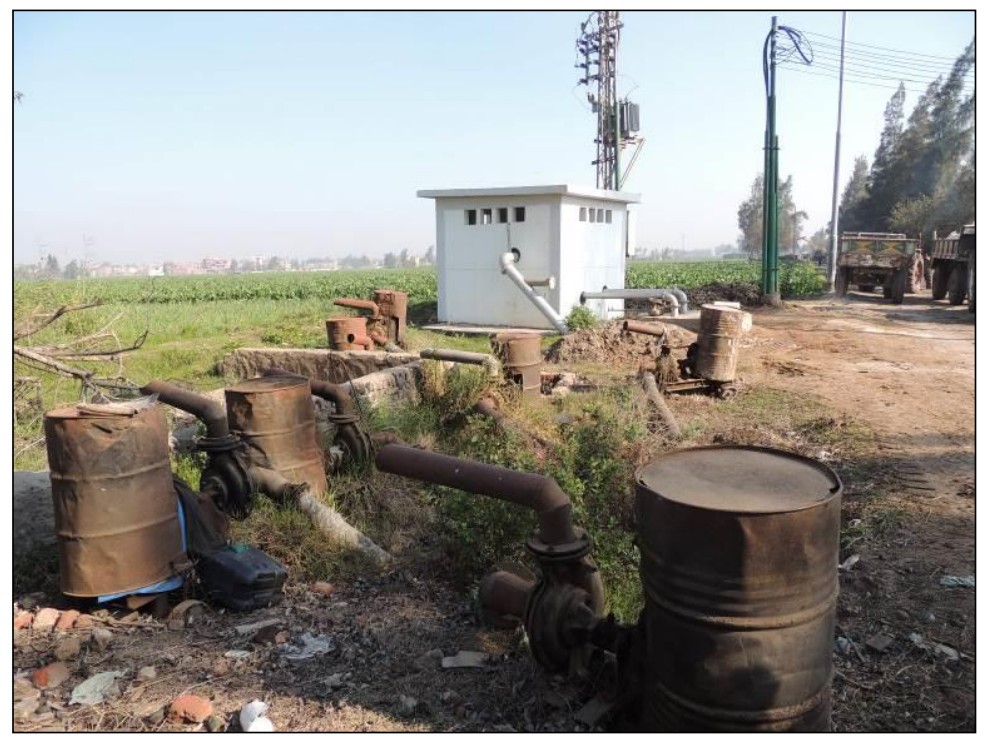

Fig. 3. The farmers were still using their old pumps with the improved system 
the conveyance losses, and the improved Mesqas became just tools to ease the irrigation effort. Mixing both systems could reduce the conflicts between farmers, but on the expense of the efficiency.

Based on discussions with the farmers, there are many reasons for continuing using old system:

- In most of the cases, farmers were still using of their old pumps with the new system in high consumption periods, especially during transplanting the rice.

- In some cases, the farmers use their old pumps because there was a conflict on using some waterways (El-Gamal et al 2014).

In other cases, when the new system has serious problem or stolen, farmers returned completely to their old system instead of fixing such serious problems.

Regarding the maintenance of the system, the observations showed that the maintenance level of the system is poor. Farmers aim to make the system barely work without insuring its sustainability. Poor maintenance is not only related to the knowledge or the capacity of farmers, but it is also related to the cooperation and the willingness of the farmers to share in the maintenance. Some operators commented about having spare parts or money for the maintenance that farmers are barely paying for the operation (El-Gamal et al 2014). Fig. (4) Presented examples on different levels, which could be observed along the entire improved areas. At Mesqa level (first from the left), the farmers dredge a small stream to release the leakage from a broken pipeline to the canal. They waited long time for improvement sector to fix the pipeline although the Mesqa was handed over to the farmers, and it became under their responsibility. In the second example, they used stones to stop the leakage from the valves in the improved Marwas instead of fixing or replacing it, and such situation was continued for long time as well. The third example presents the unsuitable maintenance of the electrical parts.

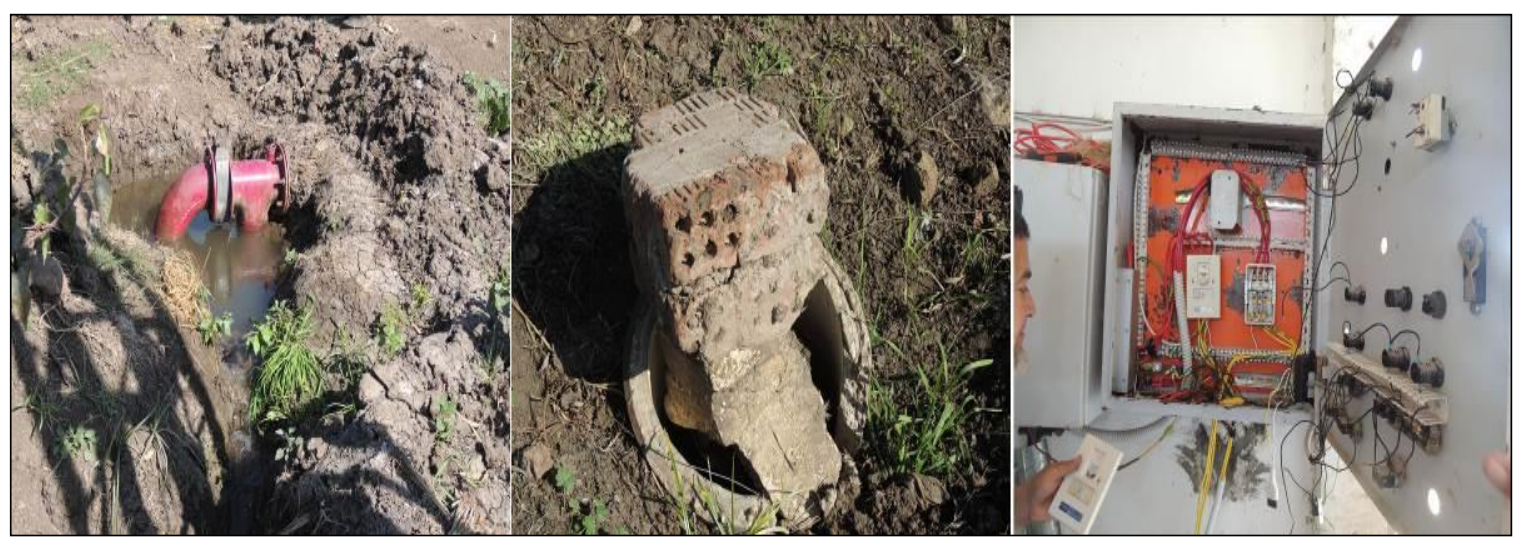

Fig. 4. Examples for poor maintenance in the improved system

\section{DISCUSSION}

The previous results highlighted the following points:

- Water Users Associations in Egypt could be classified as social-type organizations. Based on the literature, such organizations are always weak organizations. In additional, there were many social and operational challenges in last decades that imposed additional challenges for these

organizations.

- The results showed that the improved system is operated based on the natural relationships between farmers, with no obvious role of WUA boards regarding scheduling the irrigation between farmers. The operator is the main person, and he works based on reserving the irrigation turn by the farmers.

- In many cases, old lifting points were still used with the new system, and farmers changed the 


\section{Assessing the Role of Water Users Associations in Operating and Maintaining the Improved Irrigation System in Egypt}

pumps of the improved system with higher capacities. This gives the farmers the chance to work individually, which could decrease the direct conflicts, but on the expense of water use efficiency.

- The maintenance of the system is poor, and it is just to make the system work without considering the sustainability of the system.

In conclusion, irrigation in the improved areas is performed in a trend close to the same trend that started with the introduction of the individual diesel pumps at the beginning of 1980's, and which the improvement projects have been introduced to face. Improvement projects could reduce the effort and the irrigation cost, but they have not obvious effect on irrigation practices or water use efficiency, except the reduction of the conveyance losses in Mesqa and Marwa levels. New water organizations could not introduce modern type of water management, and farmers did not return to their natural cooperation around the Saqias.

Changing the approach of these organizations to business-type organizations is a radical change that requires complete change of the irrigation strategy in Egypt, and it might not be possible. The possible thing is to enhance the capacities of the current organization in order to improving water management and maintaining the sustainability of the improved system. This could be through the following:

- The first point is the firm control of the irrigation system. Old lifting points should be removed and the capacity of the pumps should be kept as design. Water should be distributed based on volumetric bases whenever possible. Controlling the system will increase the importance of the coordination between farmers. Most of the researches indicated that coordination decreased when water is abundant or very scarce or unreliable. When the coordination between farmers became a necessity, the involvement of the new water organizations became more important.

- The second point is the support (subsidizing) from the government. One general problem for social-type WUAs was "the gradual decline in government financing of the operation and maintenance of irrigation systems, whereas water user groups are making a modest contribution towards maintenance" (Plusquellec, 2002). Subsidizing the farmers should be in return for arranging themselves in associations that represent them and for following the regulations for the improved system, as was the case in other countries, such as Japan (Satoh et al 2014).
- Third point is building the capacities of these organizations. The government should focus on building the capacities that are related to the real need of these organizations, such as maintaining the system, and disregard the training for unnecessary bureaucratic procedures, which consumed big amount of money, with little lasting fruit. Burns stated, "An active, successful WUA is one, which efficiently and fairly distributes water, and maintains and improves the physical structures of the irrigation system. Farmers avoid wasting their efforts on unnecessary meetings and paperwork. Collective action in irrigation can often take advantage of existing relationships." (Burns, 1992).

With the previous steps, it should be considered that the decrease of labor force and the increase of the environmental problems in Egypt increased the acceptance of the improvement project as could be observed in last years. Monitoring results referred to a dramatic change in farmers' opinions about the improvement projects during last years (WMRI 2014). Low interest, and sometimes the resist to the project in the past prevented the government from precise implementation of the project, and the increase of accepting of the system could help the government in applying the design characteristics precisely.

\section{Conclusion and Recommendations}

Water associations in Egypt are social type organizations, and it is not affordable to change them to business type organizations due to the nature of the irrigation system and the nature of the society. As a general trend, social-type organizations are weak or paper-form organizations. The results of the current study supported that fact regarding WUAs in the improved areas in Egypt, and they showed that the irrigation is performed in a trend close to the previous trend with little involvement of WUAs boards. Other evaluation studies indicated that the irrigation efficiency had no real change in the improved areas. Both facts, the weakness of WUAs and the limitation in achieving the global targets, are connected with each other. Achieving the targets of the improvement projects should be associated with better involvement of WUAs in water distribution and in maintaining the system. This will be through the following:

- Firm control of the system, which should increase the importance of the coordination between farmers, and in consequence the importance of the involvement of WUAs; 
- The subsidizing from the government; Subsidize could help the farmers in maintaining the system after handing-over until being self-dependent. Subsidize should be in return for the acceptance of some procedures that lead to the rational use of water. To get subsidize, farmers should accept to form a WUAs that represent them and accept to keep the design of the improved Mesqa and remove all old pumps.

During performing the previous steps, the social changes should be considered and the government should take advantage from the gradual increase in accepting the improvement projects to apply the project more precisely in order to improve irrigation efficiency and to avoid water crises in the future.

\section{REFERENCES}

Ayeb H. 2013. La crise de la société rurale en Egypte - La fin du Fellah? Translated to Arabic by El-Batrawy, M., The National Center for Translation, Cairo, Egypt. pp. 244-253.

Bruns B. 1992. "Just Enough Organization: Water Users Associations and Episodic Mobilization." http://www.bryanbruns.com/enough.pdf

El-Gamal T., Masayoshi S. and Nahla Z. 2014. "The coordination between farmers in the Nile Delta under Different Improvement \& Water Availability Conditions", 22nd international congress on Irrigation and Drainage, Republic of Korea, 14-20 September, 2014, pp. 9-11.

Groenfeldt D. and Svendsen M. 2000. "Case Studies in Participatory Irrigation Management", WBI Learning Resources Series, World Bank Institute, Washington, DC, UAS, pp. 1-2.

Hvidt M. 1998. Water, Technology and Development (Upgrading Egypt's Irrigation System). Tauris Academic Studies. New York, USA, 60 p.
Johnson S.H. 1997. Irrigation Management Transfer in Mexico: A Strategy to Achieve Irrigation District Sustainability. International Irrigation Management Institute, Research Report \# 16, pp. 11-12.

Kloezen W.H., Garcés-Restrepo C. and Johnson S.H. 1997. "Impact assessment of Irrigation Management Transfer in the Alto Rio Lerma Irrigation District, Mexico" IIMI Research Report No. 15. Colombo, Sri Lanka: International Irrigation Management Institute, pp. 2-3.

MacDonald M. and Sabbour A. 2008. "Irrigation Improvement Project - Final Completion Report" Cairo, Egypt, pp. 12-23.

Mahgoub Y. 2001. "The Transformation of Rural Settlement and Dwellings in Egypt", pp. 1-36. https://www.researchgate.net/publication/28905 $\underline{6132}$

Plusquellec H. 2002. How design, management and policy affect the performance of irrigation projects - Emerging modernization procedures and design standards. FAO, Bangkok, Thailand, $45 \mathrm{p}$.

Satoh M., Nahla Z., El-Gamal T. and Yuan X. 2014. "Necessity for Government Intervention for Successful Cooperation of Farmers for Rational Water Use in Japan and Egypt", 22nd international congress on Irrigation and Drainage, Republic of Korea, 14-20 September, $6 \mathrm{p}$.

Svendsen M. 2001. Irrigation Management Transfer in Turkey. International E-Mail Conference on Irrigation Management Transfer, June 2001, pp. 10-16.

Water Management Research Institute (WMRI), 2014. "Monitoring and Evaluation of Integrated Irrigation Improvement \& Management Project Summer 2014", unpublished reported pp. 6869. 


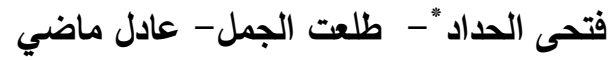 \\ معهد بحوث إدارة المياهوطرق الري - المركز القومي لبحوث المياه-وزارة الموارد المائية والري -القناطر الخيرية - \\ القليوبية- مصر ليحر الكيان
}

*Corresponding author: elhadad1652005@yahoo.com

Received 27 November, 2019

Accepted 29 April, 2020

لمسئولية التشغيل في نظام الري المطور فإن المُشخل هو

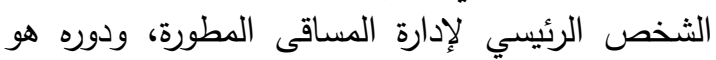

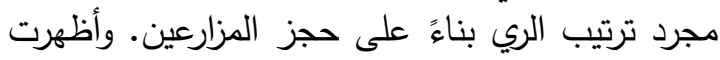

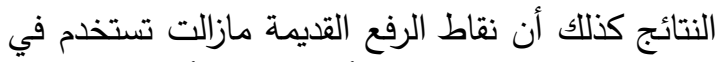

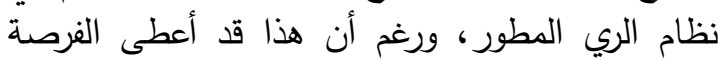

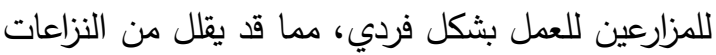

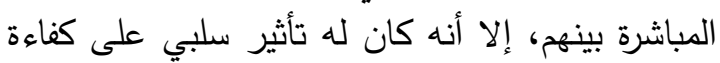

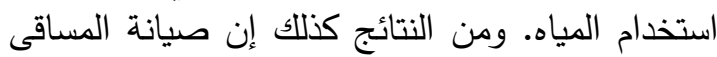

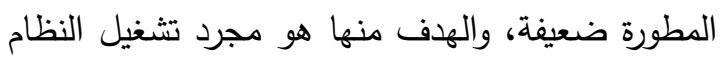

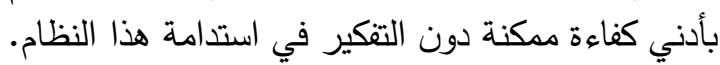

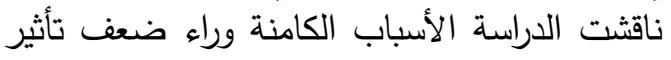

مستخدمي المياه بما في ذلك خصائص التصن هذه المنظمات والعوامل المختلفة التي تئوثر على أدائها. وفي نلى نهاية الدراسة، تم اقتراح الخطوات اللازمة لتحسين قدرات هذئ ولته

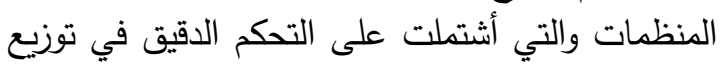

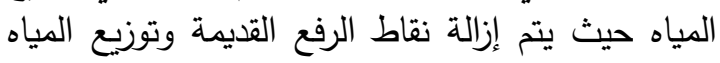
على الترع بالتصرفات والذي سيؤدى لزيادة أهمية التعاون التيع التيان بين المزارعين وبالتالي لزيادة أهمية روابط مستخدي لزيادي الهيدي التعاني

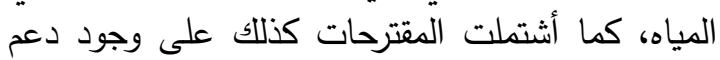

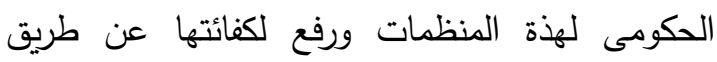
التدريب لحين قدرتها على أداء دورها بكفاءة.

الكلمات المفتاحية: التسيق بين المزارعين، جمعيات مستخدمي المياه، تطوير الري لمئي

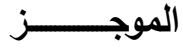

تبحث الدراسة الحالية دور جمعيات مستخدمي

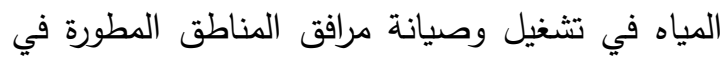

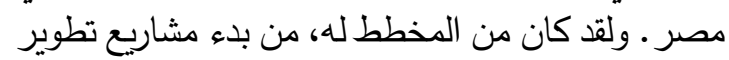

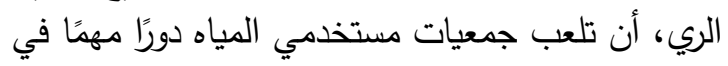

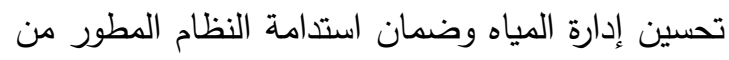

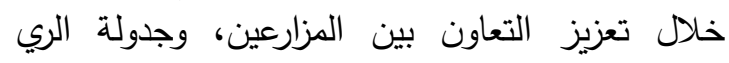
والحفاظ على المساقي المطورة. وتهدف الدراسة الحالية إلى التحقق من الوضع التع الفعلي

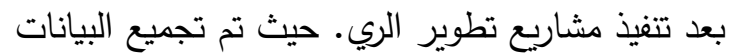

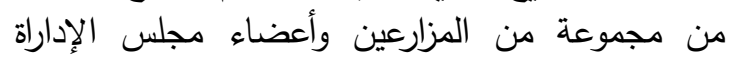

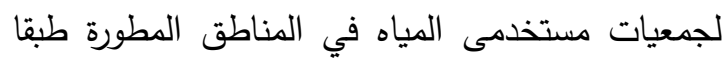

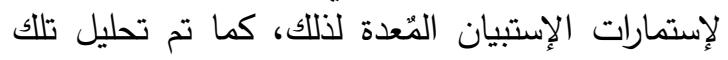

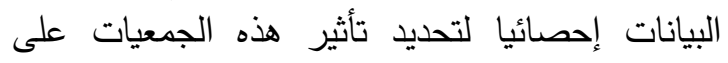
مشاريع تطوير الري. وأهم النتائج التي توصلت إليها اليها الدراسة أن تأثير

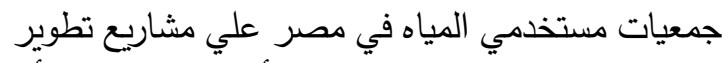

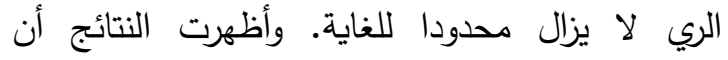

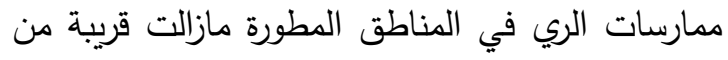

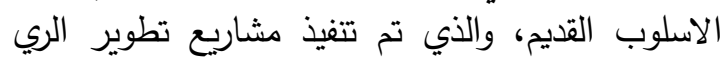

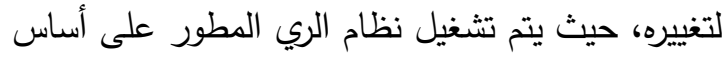

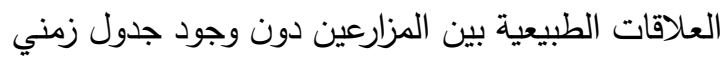
محدد للري يهدف إلى تحسين إدارة المياه. وبالنسبة
تحكيم: ا.د على البحراوي

ا.د أسعد عبدالقادر درباله اليجاي 